\title{
The Global Infrastructure Public-Private Partnership and the Extra- Territorial Politics of Collective Provision: The Case of Regional Rail Transit in Denver, USA
}

\author{
by \\ Andrew E.G. Jonas \\ Geography, School of Environmental Sciences \\ University of Hull \\ Hull, UK \\ A.E.Jonas@hull.ac.uk \\ Andrew R. Goetz \\ Department of Geography \& the Environment \\ University of Denver \\ Colorado, USA \\ andrew.goetz@du.edu
}

Sylvia Brady

Department of Geography \& the Environment

University of Denver

Colorado, USA

Sylvia.Brady@du.edu

This is the Accepted Manuscript version of an article published in Urban Studies

DOI: 10.1177/0042098018811506

Special issue on Funding, Financing and Governing Urban Infrastructure

This pre-proof version: October 2018

\begin{abstract}
Drawing upon a case study of regional transit in Denver, Colorado, this paper describes and accounts for the emergence of the global infrastructure public-private partnership (GIP3) as a novel extra-territorial mechanism for financing and delivering transportation infrastructure
\end{abstract}


projects across large metropolitan regions in the United States (US). Unlike traditional locally-funded public-private partnerships, a GIP3 involves a global (i.e. extra-territorial) consortium of private sector construction firms and investors which enters into a long-term contract with a regional public agency to finance, operate, maintain and deliver strategic investments in transportation infrastructure. In 2004, Denver region voters approved a sales tax increase to fund the Denver Regional Transportation District (RTD)'s \$4.7 billion FasTracks programme, a 122-mile extension of light and commuter rail along six corridors. Faced with a shortfall in regional funding, the Denver RTD subsequently entered into a contract with a GIP3 consortium to finance and deliver the Eagle P3 project, a major extension of the FasTracks system to Denver International Airport. The paper argues that future research on GIP3 contractual agreements needs to consider the local control of infrastructure assets and the integrity of supporting regional collaborative governance arrangements.

Key words: public-private partnerships, infrastructure finance, regional transit, collective provision, Denver, USA

\section{Introduction}

In the United States (US), fiscal austerity continues to pose a number of challenges for those public agencies responsible for funding, financing and delivering regional transportation infrastructure projects, such as light and commuter rail systems. A well-known problem is the disparity between metropolitan-wide demands for infrastructure and the capacity of local jurisdictions to raise sufficient revenue to fund, finance and deliver the required infrastructure at little or no additional cost for local taxpayers. Solutions to the socalled metropolitan fiscal disparity issue hitherto have involved inter alia the creation of regional special purpose districts, metropolitan-wide revenue-sharing agreements, and greater regional collaboration across formal municipal, county and, increasingly, metropolitan political boundaries (Bish, 1971; Ostrom, 1990; Hall and Jonas, 2014; Wachsmuth, 2015). Faced, however, with mounting shortfalls in local funding, and federal government retrenchment from capital investments, regional agencies are now turning to extra-territorial (i.e. global) institutional mechanisms in order to raise additional capital and arrange new financing terms for infrastructure projects. This paper offers a fresh perspective on such developments by describing and explaining the emergence of the global infrastructure publicprivate partnership (GIP3) as a novel extra-territorial mechanism for funding, financing and 
delivering transportation infrastructure projects across large and growing metropolitan regions in the US.

A GIP3 is defined as a private consortium of international construction firms, operators and investors which enters into a long-term contract (typically lasting more than twenty years) with a regional public agency to finance, deliver, operate and maintain a major infrastructure project. Unlike traditional public-private partnership (P3) arrangements which, in the US, have almost exclusively relied upon local funding, a GIP3 raises a significant portion of project capital in global equity and bond markets. Whereas the regional agency potentially benefits by resolving short-term cash-flow problems, reduced public borrowing costs, spreading financing, construction, and operating risks, and delivering the service or infrastructure on time and at lower cost, local contractors, suppliers and other local businesses profit from subcontracting arrangements with the GIP3 consortium.

Local and regional authorities in many countries are familiar with private finance initiatives and other P3 mechanisms used to finance and deliver a variety of infrastructure projects, ranging from hospitals to water systems and toll roads (Allen and Pryke, 2013, O’Neill, 2013). Although public agencies in the US are likewise turning to P3s, major urban infrastructure projects are heavily dependent upon local funding from inter alia sales taxes, fees and user charges, as well as voter-approved municipal and revenue bonds (Sbragia, 1996). Such reliance upon local sources of funding, in turn, underpins the problem of local dependence (Cox and Mair, 1988), which remains an enduring feature of the politics of metropolitan economic development in the US (Cox, 2011). Efforts to mitigate the problem hitherto have involved political lobbying on behalf of developers, local governments and other members of the metropolitan growth coalition for additional regional, state and/or federal funding (Logan and Molotch, 1987). Nonetheless, confronted with extreme austerity measures and reduced federal funding for infrastructure, municipal governments throughout the US are entering into all sorts of novel institutional relationships with the private sector in order to raise private capital for public infrastructure projects (Kirkpatrick and Smith, 2011; Hall and Jonas, 2014). For their part, regional transit officials are turning to the new generation of GIP3s in order to cover a growing deficit in the local and regional funding of collective infrastructure provision.

At the same time, the US federal government - notably the Federal Transit Administration (FTA) - is encouraging regional transportation agencies to experiment with new P3 arrangements, which are designed to reallocate risk from the public to the private sector, as a condition of a federal grant funding agreement. In this context, a GIP3 represents 
an integrated project funding, financing and delivery mechanism rather than a pure form of infrastructure privatisation. In order to guarantee project delivery and the integrity of local assets (e.g. tracks, equipment, buildings, etc.), GIP3 contractual agreements typically include provisions around the future control of such assets should the consortium fail to deliver. The precise terms of such a contract, in turn, could play a significant part in mitigating the problem of local dependence, averting potential opposition from local voters, and strengthening existing collaborations between local governments, politicians and metropolitan growth coalitions, all of whom are dependent to a greater or lesser degree upon the efficient provision of infrastructure. In these respects, knowledge of the circumstances surrounding a contractual agreement between a GIP3 and a regional public authority could shed light on a new and potentially significant trajectory in the territorial politics of collective provision in the US (cf. Jonas et al. 2010).

With these considerations in mind, this paper examines a novel GIP3 arrangement created to fund, finance and deliver additional extensions to regional transportation infrastructure in the Metro Denver region in Colorado. In 2004, Denver area residents voted to expand the existing regional mass transit system operated by the Denver Regional Transportation District (RTD). The $\$ 4.7$ billion FasTracks programme involved a 122-mile extension of light and commuter rail along six corridors in the Metro Denver region. However, confronting a subsequent shortfall in regional funding, the Denver RTD entered into a contractual agreement with a private sector-led global consortium to deliver the Eagle P3 project, a major extension of rail services from downtown Denver to Denver International Airport and nearby suburbs. Denver RTD had previous experience with private sector involvement through its outsourcing of some bus services to private companies as well as its design-build P3 for the Southeast Corridor light rail line completed in 2006. Still, the decision to expand private sector involvement in the Eagle P3 project represented a major step change in its infrastructure provision. Crucial factors shaping the Eagle P3 contractual agreement were the desire to protect local control of infrastructure assets and preserve the territorial integrity of Metro Denver's collaborative approach to regional economic development, both of which were threatened by the precarious fiscal predicament of the FasTracks project.

The paper reports the findings of a study of new transit P3s in Denver conducted between 2010 and 2017. The main aims of the study were to: (1) evaluate the effectiveness of new transit P3 arrangements in resolving a regional crisis in infrastructure funding; and (2) assess the impact of such arrangements on Denver's existing model of collaborative regional 
governance. The empirical research involved an analysis of secondary sources, including published public documents and metropolitan newspaper articles, as well as face-to-face interviews conducted with twenty stakeholders in Metro Denver which were designed to solicit contrasting views on new transit P3 arrangements. ${ }^{\mathrm{i}}$ Potential interviewees were identified on the basis of local knowledge, stakeholder referrals, and secondary sources. As such they were not representative of the wider Denver region population but nevertheless included a broad cross-section of public and private sector actors involved in the planning, financing, operation and/or delivery of regional transportation projects in Metro Denver. We conducted six further interviews with regional transit officials in other US cities embarking on major transit system extensions and representatives of global infrastructure investment banks based in London, United Kingdom. The latter provided an international perspective on the role of GIP3s in financing transportation infrastructure projects in the US and worldwide.

The first section of the paper documents the emergence of new types of P3 arrangements designed to fund, finance and deliver regional transportation infrastructure projects in the US. Subsequent sections examine the central role played by a GIP3 in funding, financing and delivering the Eagle P3 project in Metro Denver, one of the first examples of such an arrangement and the largest rail transit public-private partnership in recent US history. The analysis highlights the role of local dependence in shaping the negotiation of a long-term contractual arrangement between the GIP3, the Denver RTD and regional stakeholders. Key points of contention and negotiation centred around the local control of infrastructure assets and the long-term integrity of Denver's approach to regional collaboration. The paper concludes with some wider reflections on the changing landscape of global infrastructure financing and raises questions for future research into the role of the GIP3 in the new territorial politics of collective infrastructure provision.

\section{The role of $\mathrm{P3s}$ in financing transportation infrastructure}

Often closely associated with the rise and spread of neoliberal urbanism in the 1980s and 1990s (Jessop et al. 1999), innovative P3 mechanisms have been widely used over subsequent decades to deliver transit and other urban infrastructure projects throughout the world (Mandri-Perrott, 2009; Torrance, 2008). If local entrepreneurialism is deeply ingrained in the institutions and financial practices of American local government (Sbragia, 1996), the US is nevertheless a relative latecomer to the global P3 scene. Since at least the early nineteenth century, US local governments have raised capital for infrastructure projects, such as canals, roads and sewerage systems, primarily from the sale of municipal and revenue 
bonds. Issued against the promise of future revenue from local taxes and service charges, these bonds are, in effect, legal agreements between local public and private sector interests lasting the lifetime of the bond issue, which can be up to thirty years. Given such long-term local commitments, banks and other locally dependent business interests have a substantial material stake in the further expansion of the local economy and tax base (Cox and Mair, 1988).

In order to realise future gains from their investments, locally dependent businesses strive to nurture enduring local social relationships. When it comes to local investments in infrastructure, local knowledge is a key consideration. For example, access to detailed knowledge of local contractual arrangements governing the availability and supply of necessary social and transportation infrastructure (e.g. water, sewerage, etc.) at specific locations across a metropolitan area can be critical to the realisation of local interests in urban development (Cox and Jonas, 1993). An additional consideration is how to secure local voter approval for a proposed bond issue. Failing that, P3 mechanisms such as Tax Increment Financing (TIF) are now widely used to raise capital for infrastructure projects without the need to resort to the ballot box (Hall and Jonas, 2014). In TIF schemes, a redevelopment agency accrues revenue (or tax increment) needed to pay for infrastructure from the increase in local property taxes that results directly from a major redevelopment project, such as a regional transit hub (Jonas and McCarthy, 2010).

Given intense territorial competition for inward investment, the landscape of urban infrastructure finance continues to evolve as public authorities look to other P3 mechanisms besides TIF in order to finance and deliver investments in regional transportation infrastructure. Between 1985 and 2011, 377 infrastructure projects in the US were delivered by the new generation of transportation P3 arrangements (Istrate and Puentes, 2011). In a survey of thirty-two US states, Papajohn et al. (2011: 127) found that twenty-five US states had already adopted or were planning to adopt P3s, while only seven did not plan to pursue them. The number of rail transit P3s in the US is small but growing (Thomas, 2014; MandriPerrott, 2009). Between 1989 and 2011, eighty-one per cent of transportation P3s in the US involved highways, bridges and tunnels, whereas nineteen per cent were for rail projects (Istrate and Puentes, 2011).

Recent growth in P3 infrastructure projects in the US is sustained by claims that the latest generation of P3 financing arrangements can deliver such projects faster and at a lower price than more conventional forms of public-sector borrowing. For example, in the United Kingdom (UK) the National Audit Office found that only twenty-four per cent of P3 projects 
were not completed on time compared to seventy per cent of projects delivered by traditional methods, and budgets were exceeded in twenty-two per cent of P3s versus seventy-three per cent of traditional procurements (NAO, 2003). Proponents claim that P3 projects benefit from technological expertise available from the private sector especially during the construction and operation phases of a project. They further argue that P3 innovation leads to a better quality infrastructure product at a lower cost (Thomas, 2014: 6; Papajohn et al., 2011, pp. 130-131; interview, infrastructure financier, London, May 2016). During P3 contract negotiations, the public sector can stipulate what is required from the project and impose penalties on the private consortium at any stage of a project if output specifications are not achieved (Lam and Javed, 2015). Moreover, P3s increase the availability of capital funds to a public agency, allowing it to finance an infrastructure project over a longer time-period and re-allocate risk to the private sector accordingly. Papajohn et al. (2011) found that in more than half of the US states P3s were implemented because of financing reasons, while in twenty-one per cent of cases P3s were set up for cost-saving reasons. However, they further found that risk transfer was not a primary reason for setting up a P3 even though risk allocation remains a crucial component of contractual negotiations.

Although the use of private equity to finance and deliver transportation P3 projects is on the rise, the US nevertheless continues to lag behind other countries. Indeed, the Organisation for Economic Co-operation and Development (OECD) has described the US infrastructure market as "immature" in comparison to that of other OECD states (cited in Roumeliotis, 2012). Factors highlighted by the OECD include: the territorially fragmented system of public administration in the US; competition between cities, counties and states for private investment; a complex state-by-state public procurement regime; and a dearth of state and federal subsidies for major infrastructure projects. The historically strong federal-state partnership in overseeing transportation infrastructure provision, such as the 90 per cent federal funding for the construction of the Interstate Highway System, has left little room for global private equity investors. Taken together, these factors necessitate of such investors "a more pro-active approach to securing mandates on the ground" (cited in Caon, 2014).

In the meantime, the widespread use of $\mathrm{P} 3 \mathrm{~s}$ to deliver major public infrastructure projects has become a focus of critical academic scrutiny and growing public skepticism. Recent studies suggest that the initial transaction costs are much higher for a P3 compared to conventional public sector-funded projects because of the need to hire expensive legal expertise to negotiate increasingly complicated contractual agreements (Valila, 2005). Critics have further concerns about the loss of public accountability and transparency when the 
private sector takes over the operation of a major public asset (Siemiatycki, 2006; Forrer et al., 2010). Siemiatycki (2006) analysed the Richmond-Airport-Vancouver (RAV) urban rail line P3 in Canada and found that it did not deliver on expected benefits, such as reducing costs and encouraging innovation. Analyses revealed that the private interest used two pension funds largely composed of public employee retirement savings as investments for the project (Palmer, 2005; Schiller and Kenworthy, 2018). Over the longer term, there were frequent disagreements between partners over concession agreements, resulting in lawsuits and, eventually, the public sector taking over management of major infrastructure assets. In a follow-up comparative study, Siemiatycki (2009) found that, while P3s were effective at raising funds for new facilities and transferring some financial risks to the private sector, there was often a lack of meaningful community engagement in project planning. Further studies highlight the recent experiences of US toll roads and highway infrastructure projects, some of which have failed and/or returned to public management (van der Hilst, 2012; Reinhardt and Utt, 2012). Such failures feed into growing public skepticism about the longterm sustainability of $\mathrm{P} 3$ arrangements.

Not only do experiences and outcomes vary between countries but also, within the US, P3 arrangements differ markedly from sector to sector, city to city, and project to project. Design-build (DB) and design-build-operate-maintain (DBOM) are the two most common P3 models, with DB contracts amounting to sixty-two per cent of the total transport P3s active in the US from 1989 to 2011 (Thomas, 2014). In the DB model, the public agency develops certain performance specifications for the project but the detailed design is the responsibility of the private consortium, enabling it to exploit economies and reduce project costs. DBOM adds operations and maintenance responsibilities to the contract, which is usually for a period of fifteen or more years. A full design-build-finance-operate-maintain (DBFOM) delivery method can further transfer financial risk to the private sector as well as generate project lifecycle cost savings (Thomas, 2014). Table 1 provides examples of some of the largest (measured in terms of total cost or capital value) DBFOM and DBOM P3 rail transit projects either under construction, or recently completed, in the US.

\begin{tabular}{|l|l|l|l|l|}
\hline Project name & Description & P3 model & Principle partners & \multicolumn{1}{|c|}{$\begin{array}{c}\text { Capital value, } \\
\text { revenue and } \\
\text { financing sources }\end{array}$} \\
\hline $\begin{array}{l}\text { Purple Line, } \\
\text { Washington DC }\end{array}$ & $\begin{array}{l}26 \mathrm{~km} \text { light rail } \\
\text { line in northern } \\
\text { Washington DC }\end{array}$ & DBFOM & $\begin{array}{l}\text { Maryland Department } \\
\text { of Transportation, } \\
\text { Maryland Transit } \\
\text { Administration and } \\
\text { Purple Line Transit }\end{array}$ & $\begin{array}{l}\$ 5.6 \text { billion including } \\
\$ 875 \text { million } \\
\text { Transportation } \\
\text { Infrastructure Finance } \\
\text { Innovation Act loan }\end{array}$ \\
\hline
\end{tabular}




\begin{tabular}{|c|c|c|c|c|}
\hline & & & $\begin{array}{l}\text { Partners (Meridiam, } \\
\text { Fluor Enterprises, Star } \\
\text { America) }\end{array}$ & $\begin{array}{l}\text { from US DOT and } \$ 313 \\
\text { million private activity } \\
\text { bonds issued by the } \\
\text { Maryland Economic } \\
\text { Development } \\
\text { Corporation }\end{array}$ \\
\hline $\begin{array}{l}\text { Hudson-Bergen } \\
\text { Light Rail, New } \\
\text { Jersey }\end{array}$ & $\begin{array}{l}33 \mathrm{~km} \text { light rail } \\
\text { running north- } \\
\text { south along the } \\
\text { Hudson River } \\
\text { waterfront, New } \\
\text { Jersey }\end{array}$ & DBOM & $\begin{array}{l}\text { New Jersey Transit, } \\
21 \text { st Century Rail } \\
\text { Corporation (URS } \\
\text { Washington Division, } \\
\text { Itochu Rail Car, } \\
\text { Kinkisharo USA) }\end{array}$ & $\begin{array}{l}\$ 2.3 \text { billion including } \\
\text { FTA full funding grant } \\
\text { agreements, grant } \\
\text { anticipation notes and } \\
\text { State Transportation } \\
\text { Trust Fund }\end{array}$ \\
\hline $\begin{array}{l}\text { Eagle P3, } \\
\text { Denver, } \\
\text { Colorado }\end{array}$ & $\begin{array}{l}37 \mathrm{~km} \text { light and } \\
\text { commuter rail } \\
\text { extension from } \\
\text { Denver Union } \\
\text { Station to } \\
\text { Denver } \\
\text { International } \\
\text { Airport plus } \\
\text { two other short } \\
\text { extensions to } \\
\text { Denver area } \\
\text { suburbs }\end{array}$ & DBFOM & $\begin{array}{l}\text { Denver Regional } \\
\text { Transportation District } \\
\text { (RTD), Denver Transit } \\
\text { Partners (DTP) (Fluor } \\
\text { Enterprises, Uberior } \\
\text { Investments and Laing } \\
\text { Investments) }\end{array}$ & $\begin{array}{l}\$ 2.2 \text { billion comprised } \\
\text { of } \$ 1 \text { billion federal } \\
\text { grant, RTD sales tax } \\
\text { bonds and private equity } \\
\text { raised by DTP }\end{array}$ \\
\hline $\begin{array}{l}\text { Jamaica-JFK } \\
\text { Airtrain, New } \\
\text { York }\end{array}$ & $\begin{array}{l}13 \mathrm{~km} \text { rail link } \\
\text { to John F. } \\
\text { Kennedy (JFK) } \\
\text { airport }\end{array}$ & DBOM & $\begin{array}{l}\text { Port Authority of New } \\
\text { York and New Jersey } \\
\text { (PANYNJ), Skanska/ } \\
\text { Bombardier }\end{array}$ & $\begin{array}{l}\text { \$1.9 billion including } \\
\text { Federal Passenger } \\
\text { Facility Charge revenue } \\
\text { and capital raised by } \\
\text { PANYNJ }\end{array}$ \\
\hline
\end{tabular}

Table 1: Examples of recent light and commuter rail transit $\mathrm{P} 3$ projects in the US with a capital value of more than US\$1 billion

Sources: Barrow (2016); Gosling and Freeman (2012); Grisby (2015); RTD FasTracks (2015a); US DOT (n.d.).

The US Department of Transportation (USDOT) defines a P3 as a form of procurement. According to the USDOT's 2004 Report to Congress on Public-Private Partnerships,

"[a] public-private partnership is a contractual agreement formed between public and private sector partners, which allows more private sector participation than is traditional. The agreements usually involve a government agency contracting with a private company to renovate, construct, operate, maintain, and/or manage a facility or system.” (Cited in FHWA, 2007: no page nos.) 
Given such a broad definition, there is considerable scope for a regional public agency to negotiate individual P3 arrangements for different projects within its jurisdiction. Private sector financing does not have to be a significant component of the P3 structure, but global procurement and financing has nonetheless become more prevalent in recent years.

Pension funds have become major sources of global investments in urban infrastructure projects worldwide and increasingly in the US too (Clark and Evans, 1998; Torrance, 2008). The potential returns and risks associated with such investments are arguably much greater than established public financing methods, such as government bonds, necessitating the negotiation of formal contracts between parties often lasting more than twenty years. However, the negotiation of such contracts can itself be problematic given that the performance of investments is not only a function of the knowledge and expertise of pension fund managers but also of long-term relations of trust established between investors and the owners and operators of the infrastructure facilities in question (Clark and Evans, 1998). In the US, given the enduring problem of local dependence, access to local knowledge and the degree local control of strategic assets are especially controversial features of any infrastructure-related contractual agreements.

We now examine the Denver Eagle P3 project, which is of international significance because it is the first full transit DBFOM in the US and is often cited by transit officials in other cities and metropolitan regions as a model for how to finance and deliver regional transit extensions (interview, regional transit official, Seattle, April 2017). The remaining sections are based on a wider study of transit P3s and regional governance in the Metro Denver region undertaken between 2010 and 2017.

\section{Financing mass transit and a crisis of regional provision in Metro Denver}

Since the early 1990s, public officials and business leaders in the Denver Metro region have striven to nurture robust institutions of regional collaboration in order to secure public support and drive forward public investment in major regional infrastructure and economic development projects (Jonas et al., 2014). Investment in the expansion of Denver's mass transit rail system through the FasTracks programme represents the latest in a series of voter-approved regional infrastructure projects, which have included the construction of Denver International Airport (DIA) in neighbouring Adams County and its annexation to the City of Denver in the late 1980s. This section examines the recent history of the FasTracks system and sets the context for RTD's decision to enter into a contract with a GIP3 to complete a major extension of the system to DIA. 
In November 2004, voters in the Denver RTD's jurisdiction (which includes all or part of eight counties and the City of Denver) approved a 0.4 per cent increase in the regional sales tax to support the FasTracks programme, a 122-mile extension of Denver's existing light and commuter rail system (Lieb, 2004). FasTracks aimed to expand rail transit into six new corridors, including a new link to DIA, extend three existing rail corridor lines and a bus rapid transit line to Boulder, and redevelop Denver Union Station into a multimodal transportation hub for intercity and regional rail and bus service. Estimated in 2004 to cost $\$ 4.7$ billion, FasTracks was, at that time, one of the largest urban rail mass transit construction projects in the US (Lieb, op. cit.).

The FasTracks regional ballot proposal had substantial backing from the metropolitan growth coalition comprised of the Metro Denver Chamber of Commerce and the Metro Mayors Caucus (MMC). MMC was established in 1993 to operate as a regional mechanism for brokering conflicts between the City of Denver and surrounding counties around inward investment. Over the ensuing years, the MMC secured significant political compromises around a range of controversial regional growth issues arising from land use planning, smart growth policies, and the provision of infrastructure (Goetz, 2013; Rusk, 2003). However, transportation infrastructure proved a major political challenge due in part to longstanding tensions within the Denver Regional Council of Governments (DRCOG), a multicounty planning organisation established in the 1950s. In the 1980s, DRCOG adopted a plan to extend rapid transit throughout the Metro Denver region (DRCOG, 2005). However, its subsequent efforts to build a regional consensus in support of a rail transit programme failed. Nonetheless, the FasTracks initiative was eventually successful, securing 57.2 per cent of the regional vote in 2004. Its success has been attributed to MMC's ability to build a political consensus in support of regional economic development projects among member municipalities, regional business groups and civic organisations (Katz and Bradley, 2014).

Construction delays and escalating costs of materials soon led to a rapid increase in the costs of the FasTracks project from US $\$ 4.7$ billion in 2004 to an estimated $\$ 7.8$ billion in 2012. The project's dire fiscal predicament was exacerbated by a regional economic downturn occurring in the wake of the global financial crisis of 2007-8, which forced RTD to revise downwards its projected revenues from the regional sales tax. To offset the projected shortfall, some US\$397 million in revenue bonds were issued in 2010 to finance the FasTracks system. These bonds were given the lowest possible investment grade ratings (Baa3 and BBB-) by respective credit rating agencies, which further threatened the financial viability of the project (Long, 2012). In its 2011 Annual Report, RTD estimated that 
FasTracks required an additional $\$ 2.7$ billion to complete (RTD, 2012: 25). Nevertheless, Denver's then mayor, John Hickenlooper, remained committed to FasTracks and pushed for funding solutions that preserved the integrity of Denver's regional governance model, which he continued to support after becoming Governor of the State of Colorado.

Given the shortfall in regional funding, extensions to the FasTracks system were not likely to be completed within the original twelve-year project timeframe, a factor that threatened to fragment regional political consensus around which corridors would be constructed and which would be delayed indefinitely (Lieb, 2008). Responding to this combined regional fiscal and political crisis, Denver RTD considered shortening the length of proposed rail corridors; but this provoked a backlash from public officials and voters in the affected jurisdictions, who looked to alternative local funding solutions such as TIF. RTD further sought to address the crisis by increasing the construction time of such extensions to 2034 and proposing additional regional sales tax hikes. Despite support from the MMC, the RTD Board rejected sales tax ballot proposals in, respectively, 2010, 2011 and 2012. With costs escalating, it had become clear that a regional political solution to the fiscal crisis was insufficient. RTD turned to an extra-territorial mechanism to resolve the crisis and bridge the funding gap.

\section{Searching for an extra-territorial solution: federal intervention and the GIP3}

In the wake of the global financial crisis of 2007-8, state-imposed fiscal austerity measures forced many US cities to turn to new P3 arrangements to finance and deliver public infrastructure projects (Kirkpatrick and Smith, 2011). RTD initially approached the federal government for additional funding for FasTracks. In 2007, the Federal Transit Administration (FTA) launched its Public Private Partnership Pilot Program (so-called Penta P) to encourage US transit agencies to explore how P3s could be set up to mitigate public risk on federally funded transportation projects. With the election of President Barack Obama in 2008, regional transportation officials in the Denver RTD looked hopefully to the federal government to cover the regional funding gap (Lieb, 2008). The Penta P Program offered an opportunity to tap into additional federal funding.

In assembling the Penta P bid, RTD packaged the East rail line to DIA, the Gold line to Arvada and Wheat Ridge, and a segment of the Northwest rail line to Westminster into the Eagle P3 project. After a bid assessment process, which included submissions from rival private consortia, the RTD selected the Denver Transit Partners (DTP) consortium for a DBFOM contract to initiate rail service on these lines by 2016, and to operate and maintain 
the lines for the remainder of the contract. Additional P3s were established with a view to completing the remaining components of the FasTracks system. For example, the plan to redevelop Denver's Union Station - the main hub in the FasTracks system - involved a P3 arrangement between RTD, DRCOG, the Colorado Department of Transportation, the City and County of Denver, and private developers, employing a mixture of local, state and federal funding and financing.

Denver RTD was one of only three regional transportation agencies in the entire US selected for the Penta P Program and, as it transpired, it was the only agency able to deliver on its original bid proposal. In May of 2011, the FTA awarded a \$1.03 billion full-funding grant agreement to the RTD for the completion of three major corridors in the Eagle P3 project. In awarding the money to Denver, the head of the FTA, Peter Rogoff, praised the RTD's plans as a "model of private-sector involvement in transportation" (cited in Lieb, 2011). A key factor in the FTA's decision was the RTD's proposal to set up a new type of P3 capable of delivering the project in a timely and cost-effective fashion.

RTD's preferred project partner was a consortium led by Macquarie Group, and included Fluor Enterprises, Ames Construction, and Balfour Beatty Rail, among others (RTD, 2009). A global investment bank specialising in financing infrastructure projects worldwide, Macquarie was selected at the expense of a rival consortium led by HSBC, Siemens, and Veolia Transport. At the time, Macquarie was expanding into the US infrastructure market, hoping to capitalize on an emerging market for privatized infrastructure assets (Roumeliotis, 2012). For example, it was involved in a $\$ 1.7$ billion upgrade of a tunnel linking the cities of Norfolk and Portsmouth in the State of Virginia and had raised a further $\$ 2$ billion to finance its future investments in the US. However, investment returns were lower than expected. According to market research conducted by Preqin, private equity vehicles that invested in US infrastructure assets raised a total of $\$ 16$ billion in 2011, which was down some forty-nine percent from 2010 (Preqin, 2012, cited in Roumeliotis, 2012). As it turned out, Macquarie planned to sell off its stake in the Eagle P3 project well before it was completed.

Macquarie contributed $\$ 2$ billion in capital towards phase one of the Eagle P3 project, of which $\$ 54$ million was an equity investment, and in return was granted a concession to run the commuter rail system upon completion (Long, 2012). The remainder of Macquarie's investment involved construction payments from the RTD. Macquarie promised to complete this second phase of the project eleven months ahead of the scheduled deadline in 2016. However, further construction delays occurred, in part, due to problems securing rights-of- 
way approvals from private rail freight companies for the use of existing tracks and/or corridors (Long, op. cit.). State of Colorado representatives expressed concerns about the management of the FasTracks programme and demanded regular audits of RTD accounts.

Macquarie eventually sold its share in Eagle P3 to Uberior Infrastructure Investments, a subsidiary of the Lloyds Banking Group, and Eagle Rail Holdings Inc., a John Laing subsidiary. As part of the sale, DTP and the RTD agreed to shorten the length of the concession agreement from 46 to 34 years. The new termination date in 2044 reflects a predicted need to replace transit rolling stock (Public Works Financing, 2010).

The major partners in the Eagle P3 consortium are established global players experienced with infrastructure projects delivered in countries around the world. DTP's private concessionaires include Fluor Enterprises, Inc., Denver Rail (Eagle) Holdings, which is a subdivision of John Laing PLC, and Aberdeen Infrastructure Investments, a unit of Aberdeen Global Infrastructure Partners LP (DTP, 2015). John Laing and Aberdeen Infrastructure Investments are the majority partners in DTP, each with a forty-five per cent stake (John Laing, 2015). ${ }^{\text {ii }}$

DTP has since nearly completed the Eagle P3 project, representing three key components of the original FasTracks programme (see Figure 1, published version). These include the East Rail Line and the Gold Line, which comprise the main East-West extension, the first segment of the Northwest Rail Line, and the Commuter Rail Maintenance Facility (a site for storing and maintaining the commuter rail vehicles that serve parts of the FasTracks system). These extensions connect downtown Denver to major new redevelopment areas including the former regional hub airport at Stapleton ${ }^{\mathrm{iii}}$ and its replacement, DIA, as well as the suburbs of Aurora, Arvada, Wheat Ridge and South Westminster. The entire project represents a significant contribution to Denver's future aspirations for planned regional economic growth (Goetz, 2013).

\section{+++Insert Figure 1 “RTD Eagle P3 Rail Project” about here+++}

While the University of Colorado A line ${ }^{\text {iv }}$ to the airport opened in April 2016, and the B line to Westminster opened in July 2016, the G line opening to Arvada and Wheat Ridge was delayed until 2018. There have been software problems with the crossing gates that caused the Federal Railroad Administration (FRA) not to allow testing to continue on the G line until the issue is corrected on both the University of Colorado A line and the B line (RTD, 2016). The service on the Airport line was also disrupted by several lightning strikes 
during summer 2016 that shut down the line for up to seven hours at a time (Goetz and Boschmann, 2018). These technical problems have called into question some of the design and building decisions made by DTP. RTD had earlier suggested to DTP an alternative design to mitigate service interruptions from lightning because it was well known that the Denver area is prone to frequent lightning strikes in the summer months. DTP did not heed RTD's advice and did not install the alternative design, citing a force majeur or "act of God" claim that the lightning was unforeseeable and thus unavoidable (Aguilar, 2016). Problems with the crossing gates staying down too long have resulted in the FRA requiring human guards to be stationed for twenty hours per day at each grade crossing to ensure that impatient motorists do not bypass the gates. The hiring of crossing guards has resulted in additional expenses over \$6 million thus far for DTP, not including penalties for delays and service shortfalls (Aguilar, 2017).

\section{Analysis and discussion: the role of local control and regional collaboration in GIP3 contractual agreements}

The Denver case study illustrates the growing importance of GIP3s in the landscape of urban infrastructure finance and governance in the US. Notably, the Eagle P3 project represents "an innovative financing and project delivery method in which a public entity partners with the private sector on a public infrastructure project” (RTD FasTracks, 2015a). Indeed, when it first granted the concession, the FTA stipulated that private capital raised for the Eagle P3 project had to represent a new kind of P3 model. Given RTD's historic dependence upon regional funding arrangements (a combination of sales taxes, fees and bonds), and facing high interest payments, falling sales tax revenues, and a regional public unwilling to vote in favour of additional taxes and bond issues, Denver RTD had little choice but to adopt a new P3 mechanism to secure federal funding and, with it, a long-term solution to the regional funding crisis. This section draws upon the findings of our interview research to examine the role of local interests and political conditions in shaping the contractual agreement between RTD and the Eagle P3 project consortium.

\section{The question of local control}

Eagle P3 is an example of a DBFOM project, meaning it involves all stages from project construction to financing, operation and maintenance (RTD FasTracks, 2015b; c). Of 
the more than $\$ 2$ billion capital commitment, $\$ 1.03$ billion comprises grant funding from the FTA, and the remainder a mixture of public funds and private financing sources (see Table 2). The RTD makes payments to the private consortium over the lifetime of the project whilst retaining ownership of all assets relating to the FasTracks system. DTP will continue to operate the project for the remainder of its contracted lifetime.

\begin{tabular}{|c|c|}
\hline Funding and financing sources & Amount (\$US millions) \\
\hline $\begin{array}{l}\text { Public funding sources: } \\
\text { - FTA Penta-P new starts grants } \\
\text { - } \text { RTD dedicated } 0.4 \% \text { FasTracks sales } \\
\text { tax revenue } \\
\text { - Other federal grants } \\
\text { - Local city and county government } \\
\text { contributions }\end{array}$ & $\begin{array}{l}1,030 \\
128 \\
57 \\
40\end{array}$ \\
\hline Total funding & 1,255 \\
\hline $\begin{array}{l}\text { Financing sources: } \\
\text { - TIFIA loan through US DOT } \\
\text { - Tax-exempt private activity bonds } \\
\text { (PABs) } \\
\text { - } \text { RTD revenue bond proceeds } \\
\text { - } \text { Private equity }^{3}\end{array}$ & $\begin{array}{l}280 \\
396 \\
57 \\
54\end{array}$ \\
\hline Total financing & 787 \\
\hline \multicolumn{2}{|c|}{$\begin{array}{l}\text { Notes: } \\
{ }^{1} \text { Financing backed by RTD pledge of revenues from } 0.4 \% \text { FasTracks sales tax and RTD } \\
\text { original } 0.6 \% \text { sales tax } \\
{ }^{2} \text { Repaid by DTP through availability payments from RTD } \\
{ }^{3} \text { Returns to concessionaire's private equity contributions paid through availability } \\
\text { payments from RTD }\end{array}$} \\
\hline
\end{tabular}

Table 2: Funding and financing sources for the Eagle P3 project (data sources: US DOT (2015); RTD FasTracks (2015a, 2015c))

Clark and Evans (1998) provide some context for understanding the relevance of local dependence for understanding the interests of the respective parties in such a contractual agreement. Amongst other factors, they argue that

" $[\mathrm{t}]$ he fact that many infrastructure facilities have political significance - being the symbolic objects in debates about governments' fiscal and social responsibilities - and 
the fact that such facilities are a crucial part of peoples' everyday lives, suggest that another category of uncertainty is the long-term public commitment to the private financing of urban infrastructure projects" (Clark and Evans, 1998, p. 308). In respect of public commitment, Denver's Eagle P3 project relies upon local procurement, sources of revenue, labour, and, perhaps most important of all, knowledge - all of which involved local social relations that have been carefully nurtured over time. The RTD's history of innovative delivery mechanisms played an especially key role in local support for the Eagle P3 arrangement. For example, a highway expansion and light rail project in Denver known as TREX was conceived in the early 1990s and built in the early 2000s using the then novel DB approach. Its success in completing the project ahead of schedule and under budget motivated regional officials to pursue similar non-traditional methods of delivering the FasTracks project. Nonetheless, not any long-term contractual arrangement would suffice. Besides securing a stream of income for the global private consortium, the contract should minimize the long-term financial risk for the local public sector, meet the needs of local contractors and suppliers, and address any lingering concerns about the loss of local control of strategic infrastructure assets held by RTD.

Whilst the private consortium is responsible for delivering on a GIP3 contract, the assets in question are ultimately owned by a public entity (in this case a regional transportation agency) for whom local control is a key consideration (cf. Clark and Evans, op. cit., p. 306). Although the RTD has less direct control of the design and building specifications of the DBFOM model compared to a design-bid-build contract, one respondent speaking on its behalf argued that 'I'm sure some people will say the owner has less control. I take the view [that] we have plenty of control of the things we should worry about" (stakeholder interview, Denver, March 2016). Arguably, the main condition for a robust GIP3 agreement is guaranteed local cost recovery. Indeed, the FTA full-funding grant agreement issued for the Eagle P3 concession awarded points for cost effectiveness, or "bang-for-buck" efficiency. Whilst other P3 arrangements used in the FasTracks programme have delivered well below initial cost estimates, the DBFOM structure used for Eagle P3 is proving to be the most cost-effective, costing \$300 million below initial internal estimates. Savings have come from extending the period of financing and accelerating the delivery of the FasTracks system, enabling RTD to allocate funds to other regional transportation projects in Denver (interviews with stakeholders, Denver, March 2016). In fact, stakeholders rate the project as financially the most effective P3 arrangement used in Metro Denver because of the improved access to the airport and the prospect of attracting new development to Adams County. ${ }^{\mathrm{v}}$ In addition, the 
Eagle P3 project has circumvented the need to return to the regional ballot box to leverage extra revenues.

\section{Preserving the integrity of collaborative regional governance}

Another theme arising from our interview-based research is the implications of the RTD's contractual agreement with DTP for the long-term integrity of Denver's model of regional collaboration, which hitherto has striven to build trust and political consensus between business organisations, voters and local governments around potentially controversial regional funding issues. Most of our respondents agree that RTD has - with one or two notable exceptions such as the aforementioned crossing gate issue - been able to extract substantial concessions from the private consortium in return for regional support for the financing deal. "There is a fairly significant and substantial appetite for long-term fairly manageable risk, fairly predictable returns, and from a financial standpoint for the concessionaire [DTP], it's good. Is it a smoking deal? I don't know. Is it a bad deal? No. But it's a good deal" (stakeholder interview, Denver, March 2016). A key factor was RTD's ability to stipulate output specifications, enabling it to impose penalties on the consortium if it did not deliver all or part of the project. In the event, the consortium has incurred significant additional expenses, such as having to demolish and rebuild the Jersey Cutoff bridge at the cost of $\$ 10$ million due to a flawed initial design, ${ }^{\mathrm{vi}}$ and over $\$ 6$ million for the crossing gate problems thus far (Aguilar, 2017).

Previous research suggests that over-reliance upon P3s fosters concerns about the loss of public accountability when the private sector takes over the operation of a major public asset such as a regional transit system (Siemiatycki, 2006). Our findings, however, suggest that such concerns can shape contractual agreements from the outset. By their nature, P3s are

“...super complex and super opaque.... It's just complicated, and I think ... if [someone has] a reason for [a $\mathrm{P} 3$ project] not to go forward, it's easy to sort of scare people about what you're delegating and outsourcing, that there is this big powerful, probably not local, consortium coming to, you know, do this thing, and so I still think $[\mathrm{P} 3 \mathrm{~s}]$ are a little vulnerable in that respect because they aren't transactions most people are going to understand" (stakeholder interview, Denver, March 2016). Nonetheless participants in contract negotiations found it a challenge to explain P3s to Denver voters, many of whom are unfamiliar with the underlying complexity of such financing arrangements. 
"I think the blame lies with the industry and the owners. We haven't done a good job of educating people about a really complex topic.... so if we want to be doing billion dollar transactions, we should probably invest a little more time and effort educating stakeholders appropriately" (stakeholder interview, Denver, July 2016).

It is further acknowledged that public and private partners involved in a large and extremely complicated GIP3 contract need to invest time and resources into public information campaigns in order to ease public suspicions about privately-financed infrastructure projects. Such concerns are justified insofar as a GIP3 project involves significant up-front costs.

On the question of whether GIP3s are more cost-effective than traditional P3 arrangements, our research found that stakeholders are worried that the financial risks associated with a badly structured contract greatly outweigh the up-front costs of hiring experts, including lawyers, designers, bankers and public relations personnel. In the absence of standardised contracts for full DBFOM agreements, the Denver RTD hired financial and legal experts from global firms, including Goldman Sachs, JP Morgan, and Freshfields to prepare the bid and negotiate terms of the consortium agreement. Nonetheless stakeholders acknowledged that reliance upon a P3 delivery model does come with extra costs:

"We [the public agency] are able to secure financing at a far better rate than what our private partners can. ... If you go down the hall, to the green-visor wearing accountant that is looking at [the interest rates and financing], the public agency accountant or CFO [Chief Financial Officer] is rarely going to be a chief supporter of P3s because they will always look at the sole financing of that portion and say, 'well you guys are still taking out this loan for $x$ dollars, and you are paying a higher rate than what we could get ourselves. Why are you doing this?' So that's where taking a look at some of the other benefits [...] really come in as far as the value, the net present value of this particular delivery mechanism" (stakeholder interview, Denver, March 2016). So the true value of the contract should, it is suggested, take into consideration the allocation of risk between the public and private sectors and the capability to build the rail lines faster. In addition, in the case of the RTD, using a P3 structure that included operations and maintenance spread out payments over a longer period of time, freeing up more money for additional FasTrack projects, and avoiding future funding "bottlenecks" (RTD, 2015).

Efforts to bring on board the public and preserve the integrity of Metro Denver's approach to regional collaboration have in the end proven crucial not only for managing tensions around the financing of the Eagle P3 project but also for delivering other P3 projects across the region. Denver RTD's ability to complete or begin construction on projects, such 
as the I-225 and North Metro lines, using savings from Eagle P3 was, in the words of one interviewee, deemed

“.... brilliant, especially along North Metro. You had such anti-Denver and anti-RTD rhetoric that was coming out of Adams County and those North Metro communities, that actually figuring out how to give them a chunk of the North Metro rail line and hold out a real hope to get the rest of it built was extremely important" (stakeholder interview, Denver, July 2016).

For some, it demonstrated a "good-faith effort" on the part of Denver to get something built for neighbouring jurisdictions such as Adams County and the City of Aurora. "It held together the broader regional coalition around transit that I think otherwise would have turned into another half-dozen factions all trying to grab the money" (stakeholder interview, Denver, July, 2016). Nonetheless, Denver's model of regional collaboration remains threatened by a pervasive "corridor versus corridor" mentality that has resulted from the fragmentation of the FasTracks system into separate P3 governance arrangements. This is especially true for the unfinished Northwest Corridor rail line to Boulder and Longmont. Although FasTracks was originally designed and funded as an integral regional transportation system, it is now in effect financed and delivered on a corridor-by-corridor basis. Whilst the system could not have been funded and financed in the absence of regional collaboration, nonetheless its completion has exposed tensions in Denver's collaborative approach to regional development.

\section{Conclusions and wider implications}

This study has examined the context and circumstances in which public authorities in the Metro Denver region turned to an extra-territorial mechanism for financing extensions to regional transit infrastructure. We have shown how additional regional funding arrangements proved necessary but ultimately insufficient solutions to the escalating costs of planned extensions to the FasTracks rail transit system, which had been approved by the region's voters in 2004. In order to complete the Eagle P3 project - a major component of the FasTracks system and one of the largest transit P3 ventures in recent US history - Denver RTD looked to a GIP3 to procure the necessary additional resources and raise capital from global private equity investments. This novel global infrastructure financing mechanism, in turn, provided Denver RTD with access to additional federal funding enabling it to complete significant components of the original FasTracks system. 
The findings of the paper have several wider research implications. First, Denver's Eagle P3 project is increasingly regarded to be a model for the new generation of transportation P3s in the US. As other cities and metropolitan regions look to innovative ways of financing major extensions to existing regional transit systems, many are turning to a new generation of GIP3 financing arrangements, making this study a timely and potentially significant benchmark for further research. Yet despite the novelty of such global arrangements, our analysis suggests that the enduring problem of local dependence - a reliance on the part of metropolitan growth coalition interests, broadly conceived, on local funding, knowledge and collaborative models of regional governance to deliver region-wide investments in infrastructure - remains a significant factor shaping contractual relations between a GIP3 and a regional transportation agency.

Second, further research is needed on the role of local political conditions in shaping contractual agreements negotiated between a regional public agency and a GIP3 consortium. The GIP3 model relies upon income extracted from fixed equity-based regional transportation infrastructure investments and assets. In the US, such investments are organized, operated and funded locally for the most part and, as such, are bound to a particular territory - in this case, a metropolitan region and its attendant flows of materials, people and capital. As Harvey (1982) argued many years ago, place-based infrastructure assets are always vulnerable to devaluation. Accordingly, potential investors tend to target territories where there is "a level of political stability and visibility on government infrastructure procurement policy" (cited in Caon, 2014). Denver's Eagle P3 project was attractive to a GIP3 because it not only relied on already-approved regional sales tax funding and newly-secured funding from the US federal government but also fiscally benefited from Denver's mature political climate of regional collaboration.

Third, there is a need for further research into the role of GIP3s in supporting or, conversely, undermining models of regional collaborative governance. Across many cities and regions, new multi-jurisdictional regional collaborative agreements between local and national governments, metropolitan growth coalitions and special purpose districts have emerged to deliver ambitious regional economic development and infrastructure projects (Wachsmuth, 2015). Although initially successful in raising regional taxes to fund the FasTracks system, such arrangements in Metro Denver ultimately proved insufficient for resolving an extended crisis in the funding of transit infrastructure. Extra-territorial intervention in the form of a contractual agreement between the regional transit district and a GIP3 was required to complete the FasTracks system. This solution was actively encouraged 
by a national transportation administration committed to aligning new P3 arrangements with collaborative regional governance, suggesting that such extra-territorial mechanisms are increasingly likely to shape future investment in regional transport infrastructure in countries, such as the US, whose governments remain ideologically and politically committed to P3 financing models.

Fourth, and finally, the paper has identified the emergence of the GIP3 as a potentially powerful new player in the territorial politics of collective infrastructure provision. The US context is especially significant given the enduring metropolitan fiscal disparity problem. The intense global competition to attract private finance to public infrastructure projects creates opportunities for metropolitan growth coalitions to exploit the problem in novel ways. On the one hand, the prospect of attracting a GIP3 might embolden members of a local growth coalition to seek to appease local public opposition to extra taxes by promising to transfer short-term risk to the private sector in exchange for socialising the costs of infrastructure over the longer-term (cf. Graham and Marvin, 2001). On the other hand, poorer local jurisdictions and their constituencies - those lacking the political and economic capacity to secure premium access to regional infrastructure - will in all likelihood continue to experience local deficits in collective provision (see Keil and Adie, 2005). This in itself need not necessarily expose regional officials and politicians to undue public criticism. As Storper (2013) argues, the metropolitan fiscal disparity problem can be managed by fostering stronger institutional bonds at the regional scale. One might even argue that the negotiation of more robust arrangements between regional political actors and a GIP3 could ensure a more equitable provision of infrastructure in the medium-to-long term.

But is the fostering of stronger mechanisms of regional collaboration always a sufficient condition? What happens, for example, when unanticipated costs associated with large-scale infrastructure projects escalate and regional collaborative arrangements fail to internalise such costs? To what extent does the presence of a GIP3 change the balance of power between public and private sector interests across a region? Or between a region and its national or global competitors? Crucially, how can the regional public interest be protected when a GIP3 project fails? As officials in other cities and metropolitan regions look increasingly to extra-territorial solutions to the regional crisis of infrastructure provision, finding answers to such questions necessitates further research on contractual agreements involving GIP3s.

\section{Notes}


1. For further details about the methods used in this study, see XXX [to be inserted].

2. Other members of the Eagle P3 consortium are global contractors, including Balfour Beatty Rail Inc. and Ames Construction.

3. The area of the former Stapleton airport has been redeveloped into a New Urbaniststyle community with over 16,000 residents as of 2014.

3. The University of Colorado acquired naming rights for the commuter rail line to DIA as part of a five-year, \$5 million deal with the RTD signed in August 2015. See: http://www.denverpost.com/2016/04/19/why-the-train-to-denver-international-airport-isnamed-the-university-of-colorado-a-line/ (accessed 15 December, 2016).

4. Denver's current mayor, Michael Hancock, has expressed an interest in developing the land around DIA and along the A-line corridor into an 'aerotropolis' or airport city as an engine for regional economic development.

5. This bridge crosses heavily used freight railroad tracks just south of I-70 along the Gold line/Northwest line alignment in the Eagle P3 project.

\section{Funding}

To be included.

\section{References}

Aberdeen Asset Management (2015) Aberdeen Asset Management in the United States. Aberdeen Asset Management. Last accessed April 2015 at: http://www.aberdeenasset.us

Aguilar, J. (2016) A-Line Design Questions That Have Caused Travel Delays Were Brought Up as Early as 2013. Denver Post, October 21, 2016 (available at: http://www.denverpost.com/2016/10/21/rtd-a-line-design-delays-lightning-issues/, accessed 7 December, 2017).

Aguilar, J. (2017) Future of RTD's A, B and G lines - long in limbo because of costly gate crossing problems - could become clearer Wednesday. Denver Post, September 27, 2017 (available at: http://www.denverpost.com/2017/09/27/rtd-a-b-g-line-light-railproblems/, accessed 7 December, 2017).

Allen, J. and Pryke, M. (2013) Financializing household water: Thames Water, MEIF, and 'ring-fenced' politics. Cambridge Journal of Regions, Economy and Society 6, pp. 419-439.

Barrow, K. (2016) Maryland Purple Line reaches financial close. International Railway Journal, 28 June (available at: http://www.railjournal.com/index.php/north- 
america/maryland-purple-line-reaches-financial-close.html, accessed 15 December, 2017).

Bish, R.L. (1971) The Public Economy of Metropolitan Areas. Chicago: Markham Series in Public Policy Analysis.

Caon, V. (2014) Aberdeen launches fifth infrastructure fund. Investment Europe, 4 August (available at: http://www.investmenteurope.net/regions/uk/aberdeen-launches-fifthinfrastructure-fund/, accessed 20 April, 2015).

Clark, G.L. and Evans, J. (1998). The private provision of urban infrastructure: financial intermediation through long-term contracts. Urban Studies 35(2), pp. 301-319.

Cox, K.R. (2011), Commentary: from the New Urban Politics to the 'New' Metropolitan Politics, Urban Studies 48, pp. 2661-2672.

Cox, K.R. and Jonas, A.E.G. (1993) Urban development, collective consumption and the politics of metropolitan fragmentation, Political Geography 12, pp. 8-37.

Cox, K.R. and Mair, A.J. (1988) Locality and community in the politics of local economic development Annals of the Association of American Geographers 78, pp. 307-325.

DRCOG (2005) DRCOG 50 th Anniversary History. Denver: DRCOG (available at: http://www.drcog.org/documents/50th\%20DRCOG\%20history\%20.pdf (accessed 5 August, 2015).

DTP (Denver Transit Partners) (2015) Welcome to Denver Transit Partners. Denver: DTP (available at: http://denvertransitpartners.com/, accessed 15 April, 2015).

FHWA (Federal Highway Administration) (2007). User Guidebook on Implementing Publicprivate Partnerships for Transportation Infrastructure Projects in the United States. Washington DC: FHWA (available at: http://www.fhwa.dot.gov/ipd/pdfs/ppp_user_guidebook_final_7-7-07.pdf, accessed 15 August, 2016).

Forrer, J., Kee, J. E., Newcomer, K. E., \& Boyer, E. (2010) Public-private partnerships and the public accountability question. Public Administration Review 70(3), pp. 475-484.

Goetz, A.R. (2013) Suburban sprawl or urban centers: tensions and contradictions of smart growth approaches in Denver, Colorado, Urban Studies 50(11), pp. 2178-2195.

Goetz, A.R. and Boschmann, E.E. (2018) Metropolitan Denver: Growth and Change in the Mile High City. Philadelphia: University of Pennsylvania Press.

Gosling, G.D. and Freeman, D. (2012) Case Study Report: John F. Kennedy International Airport Airtrain. Mineta Transportation Institute Working Paper: Research Project 2503, San Jose, CA: San Jose State University (available at: 
http://transweb.sjsu.edu/PDFs/research/2503/2503_cases/2503-cs2-jfk-airtrain.pdf, accessed 7 December, 2017).

Graham, S. and Marvin, M., (2001) Splintering Urbanism: Networked Infrastructures, Technological Mobilities and the Urban Condition. Abingdon: Routledge.

Grisby, D.C. (2015) Open for Business: The Business Case for Investment in Public Transportation. Washington DC: American Transportation Association, March (available at:

http://www.apta.com/resources/statistics/Documents/Caseforbusiness.pdf, accessed 7 December, 2017).

Hall, S. and Jonas, A.E.G. (2014) Urban fiscal austerity, infrastructure provision and the struggle for regional transit in 'Motor City'. Cambridge Journal of Regions, Economy and Society 7(1), pp. 189-206

Harvey, D.W. (1982) The Limits to Capital. Oxford: Blackwell.

Istrate, E. and Puentes, R. (2011). Moving Forward on Public-Private Partnerships: US and International Experience with PPP Units. Washington DC: Brookings Institution (available at: https://www.brookings.edu/research/moving-forward-on-public-privatepartnerships-u-s-and-international-experience-with-ppp-units, last accessed 16 August, 2016).

Jessop, B., Peck, J.A. and Tickell, A. (1999) Retooling the machine: economic crisis, state restructuring, and urban politics. In A.E.G. Jonas and D. Wilson (eds.), The Urban Growth Machine: Critical Perspectives Two Decades Later. Albany, NY: State University Press of New York, pp. 141-159.

John Laing (2015) United States: Denver Eagle P3 Project. London: John Laing PLC (available at: http://www.laing.com/project_portfolio/31/145/denver-eagle-p3-projectus.html, accessed 15 October, 2015).

Jonas, A.E.G., Goetz, A.R. and Bhattarcharjee, S. (2014) City-regionalism and the politics of collective provision: regional transportation infrastructure in Denver, USA. Urban Studies 51(11), pp. 2444-2465.

Jonas, A.E.G. and McCarthy, L. (2010) Redevelopment at all costs? A critical review and examination of the American model of urban management and regeneration. In J. Diamond, J. Liddle, A. Southern, P. Osei (eds.), Urban Regeneration Management: International Perspectives. London: Routledge, pp. 31-59. 
Jonas, A.E.G., While, A. and Gibbs, D. (2010) Managing infrastructural and service demands in new economic spaces: the new territorial politics of collective provision. Regional Studies 44(2), pp. 183-200.

Katz, B. and Bradley, J. (2014) The Metropolitan Revolution: How Cities and Metros are Fixing Our Broken Politics and Fragile Economy. New York: Brookings Institution.

Keil, R. and Adie, J.-P. (2015) 'It's not going to be suburban, it's going to be all urban': assembling post-suburbia in the Toronto and Chicago regions. International Journal of Urban and Regional Research 39, pp. 857-1066.

Kirkpatrick, O.L. and Smith, M.P. (2011) The infrastructural limits to growth: rethinking the urban growth machine in times of fiscal crisis. International Journal of Urban and Regional Research 35, pp. 477-503

Lam, P.T. I. and Javed, A.A. (2015) A comparative study on the use of output specifications for Australian and UK PPP/PFI projects, ASCE Journal of Performance of Constructed Facilities, 29(2) (available at: http://dx.doi.org/10.1061/(ASCE)CF.19435509.0000554, accessed 30 September, 2017).

Lieb, J. (2004) Voters climb aboard FasTracks tax boost - YES: 57.2\% NO: 42.8\% PRCTS: 88.4\%, The Denver Post, November 3 (available at: http://infoweb.newsbank.com, accessed 15 August, 2010).

Lieb, J. (2008) RTD to hear options on FasTracks dilemma, The Denver Post, 23 September (available at: http://infoweb.newsbank.com, accessed 15 August, 2010).

Lieb, J. (2011) Feds provide FasTracks with billion dollar assist, The Denver Post, 1 September (available at: http://infoweb.newsbank.com, accessed 15 September, 2011).

Logan, J. and Molotch, H. (1987) Urban Fortunes: The Political Economy of Place. Berkeley and Los Angeles: University of California Press.

Long, C. (2012) Denver's botched FasTracks privatization. Reuters: Analysis \& Opinion, 3 April (available at: http://blogs.reuters.com/muniland/2012/04/03/denvers-botched-fastracksprivatization/, accessed 25 April, 2015).

Mandri-Perrott, C. (2009) Private Sector Participation in Light Rail-Light Metro Transit Initiatives. The World Bank: PPIAF (Public-Private Infrastructure Advisory Facility) (available at: http://www.ppiaf.org/sites/ppiaf.org/files/publication/PSP-LightRailCMandri-Perrott.pdf, accessed 30 April, 2015). 
NAO (National Audit Office) (2003) PFI: Construction Performance. London: UK Government NAO.

O'Neill, P. (2013) The financialisation of infrastructure: the role of categorisation and property relations, Cambridge Journal of Regions, Economy and Society, 6(3), pp. 441-454.

Ostrom, E. (1990). Governing the Commons: The Evolution of Institutions for Collective Action. Cambridge and New York: Cambridge University Press.

Palmer, V. (2005). 'Private-sector portion of RAV risk isn't so private, after all', The Vancouver Sun, August 10, A3.

Papajohn, D., Cui, Q., and Bayraktar, M. E. (2011) Public-private partnerships in US transportation: Research overview and a path forward. Journal of Management in Engineering 27(3), pp. 126-135.

Preqin (2012) Private equity funding remains weak in Q4 2011. Preqin Press Release, 4 January (available at: https://www.preqin.com/docs/press/Private_Equity_Fundraising_2011.pdf, accessed 15 April, 2015).

Public Works Financing (2010) Denver Eagle P3 Financed, First U.S. Rail PPP. Westfield, NJ: Public Works Financing (W.G. Reinhardt, ed.), September (available at: http://www.pwfinance.net/document/research_reprints/7\%20denver\%20eagle.pdf, accessed 15 April, 2015).

Reinhardt, W. G. and Utt, R. D. (2012) Can Public-Private Partnerships Fill the Transportation Funding Gap? Heritage Foundation Backgrounder, 2639 (available at: http://www.heritage.org/transportation/report/can-public-private-partnerships-fill-thetransportation-funding-gap (accessed 30 September, 2015).

Roumeliotis, G. (2012) Exclusive: Macquarie eyes \$2 billion infrastructure fund-sources, Reuters: Business, 2 April (available at:

http://www.reuters.com/article/2012/04/02/us-macquarieidUSBRE8310LB20120402, accessed 15 April, 2015).

RTD (Denver Regional Transportation District) (2012) RTD 2011 Annual Report to DRCOG on FasTracks. Denver: RTD, April (available at: http://www.rtdfastracks.com/media/uploads/main/SB208_2011_report_4-3-2012.pdf, accessed 15 April, 2015).

RTD (2015) Best Practices. Denver: RTD. (available at: http://www.rtddenver.com/documents/best-practices-2015.pdf, accessed 4 September, 2018). 
RTD FasTracks (2009) RTD Board Briefing: Eagle P3 Project, Draft RFP (available at: https://admin.rtdfastracks.com/media/uploads/main/PPP_Board_briefing_010609_v5.pdf, accessed 4 September, 2018).

RTD FasTracks (2015a) Eagle P3 project. Denver: RTD (available at: http://www.rtd-fastracks.com/ep3_2, accessed 30 October, 2015).

RTD FasTracks (2015b). Eagle P3 Facts and Figures. Denver: RTD (available at: http://www.rtd-denver.com/FF-EagleP3.shtml, accessed 30 October, 2015).

RTD FasTracks (2015c) FasTracks Eagle P3 project. Denver: RTD. (available at: http://rtdfastracks.com/main_126, accessed 15 October, 2015).

RTD (2016) Inside RTD FasTracks, November 2016 (available at: http://www.rtdfastracks.com/media/uploads/main/Inside_RTD_FasTracks_NOVEMBER_2016_FIN AL.pdf, accessed 15 December, 2016).

Rusk, D. (2003) Denver Divided: Sprawl, Race, and Poverty in Denver. Denver, CO: University of Denver Morgridge College of Education.

Sbragia, A. (1996) Debt Wish: Entrepreneurial Cities, US Federalism, and Economic Development. Pittsburgh: University of Pittsburgh Press.

Schiller, P. and J. Kenworthy (2018) An Introduction to Sustainable Transportation: Planning, Policy and Implementation, $2^{\text {nd }}$ edition. London and New York: Routledge. Siemiatycki, M. (2006) Implications of private-public partnerships on the development of urban public transit infrastructure - The Case of Vancouver, Canada. Journal of Planning Education and Research 26(2), pp. 137-151.

Siemiatycki, M. (2009) Delivering transportation infrastructure through public-private partnerships: planning concerns. Journal of the American Planning Association 76(1), pp. 43-58.

Storper, M. (2013) The Keys to the City: How Economics, Institutions, Social Interaction, and Politics Shape Development. Princeton, NJ: Princeton University Press.

Thomas, L.W. (2014). Transit Public-Private Partnerships: Legal Issues. Washington DC: Transportation Research Board, Legal Research Digest 45, July.

Torrance, M. (2008) Forging glocal governance? Urban infrastructures as networked financial products. International Journal of Urban and Regional Research 32(1), pp. $1-21$.

US DOT (US Department of Transportation) (2015) Eagle P3 Project, Denver, CO. Washington DC: USDOT, 29 September (available at: 
https://www.transportation.gov/policy-initiatives/build-america/eagle-p3-projectdenver-co, accessed 3 September, 2018).

US DOT (n.d.) Project Profile: Hudson-Bergen Light Rail. Washington DC: USDOT, Federal Highway Administration (available at:

https://www.fhwa.dot.gov/ipd/project_profiles/nj_hudson_bergen.aspx\#top-bannerwrap, accessed 7 December, 2017).

Valila, T. (2005) How expensive are cost savings? On the economics of PPPs. European Investment Bank Papers 10(1), pp. 94-119.

Van der Hilst, A. (2012) Using Public-Private Partnerships to Carry Out Highway Projects. US Congress: Congressional Budget Office.

Wachsmuth, D. (2015) Megaregions and the urban question: the new strategic terrain for US urban competitiveness. In J. Harrison and M. Hoyler (eds.) (2015) Megaregions: Globalization's New Urban Form? Cheltenham: Edward Elgar, pp. 51-74. 